\title{
Hypersensitivity to seizures in $\beta$-amyloid precursor protein deficient mice
}

\author{
Joachim P. Steinbach ${ }^{1,5}$, Ulrike Müller ${ }^{2,5,6}$, Marcel Leist ${ }^{3}$, \\ Zhi-Wei $\mathrm{Li}^{2}$, Pierluigi Nicotera ${ }^{3}$ and Adriano Aguzzi ${ }^{1,4}$ \\ 1 Institute of Neuropathology, University Hospital, Zurich, Switzerland \\ 2 Institute of Molecular Biology, University of Zurich, Switzerland \\ ${ }^{3}$ Institute of Molecular Toxicology, University of Konstanz, Germany \\ ${ }^{4}$ corresponding author: Institute of Neuropathology, Schmelzbergstrasse 12, \\ CH - 8091 Switzerland. tel: +41-1-255 2107; fax: +41-1-255 4402; \\ E-mail: adriano@pathol.unizh.ch \\ ${ }^{5}$ The first two authors contributed equally to this study \\ ${ }^{6}$ Present address: Max-Planck-Institute for Brain Research, D-60528 Frankfurt, \\ Germany
}

Received 17.10.97; revised 27.2.98 accepted 13.3.98

Edited by M.Noble

\begin{abstract}
Secreted forms of the $\beta$-amyloid precursor protein ( $\beta$-APP) have neuroprotective properties in vitro and may be involved in the containment of neuronal excitation. To test whether loss of secreted forms of $\beta$-APP (sAPPs) may enhance excitotoxic responses, we injected mice homozygous for a targeted mutation of the $\beta$-APP gene $\left(\beta\right.$-APP $\left.{ }^{\Delta / \Delta}\right)$ intraperitoneally with kainic acid. We found that in these mice, kainic acid induced seizures initiated earlier, and acute mortality was enhanced compared to isogenic wild-type mice independently from the callosal agenesis phenotype observed to occur at increased frequency in APP mutant mice. Expression of $\mathrm{c}$-fos in cortex and cingulate gyrus was enhanced in $\beta$-APP ${ }^{\Delta / \Delta}$ mice, although the amount of structural damage and apoptosis in the hippocampal pyramidal cell layer and cortex was similar to that of controls. When cerebellar granule cell cultures and cortical neuronal cultures were challenged with glutamate receptor agonists, the rates of cell death and apoptosis of $\beta$-APP ${ }^{\Delta / \Delta}$ mice were indistinguishable from those of controls. Therefore, deficiency of SAPPs causes facilitation of seizure activity in the absence of enhanced cell death. Since enhanced seizures were observed also in mice homozygous for a deletion of the entire $\beta$-APP gene, this phenotype results from a loss of APP rather than from a dominant effect of $\mathrm{APP}^{\Delta}$.
\end{abstract}

Keywords: Alzheimer's disease; $\beta$-amyloid precursor protein; $\beta$ APP deficient mice; kainic acid; apoptosis; excitotoxicity; c-fos; neuronal cultures

Abbreviations: $\beta$-APP: $\beta$-amyloid precursor protein; sAPPs: secreted forms of the $\beta$-amyloid precursor protein; AD: Alzheimer's disease; APLPs: APP-like-proteins; PKC: protein kinase C; KA: kainic acid; TUNEL: In-situ nick end-labeling; GFAP: glial fibrillary acidic protein; MAP-2: microtubule associated protein-2; GCG: Cerebellar granule cell cultures

\section{Introduction}

Secreted forms of the $\beta$-amyloid precursor protein (sAPPs) are generated from the membrane-spanning holo-APP by proteolytic cleavage, and are secreted in an activitydependant manner (Nitsch et al, 1993; Selkoe, 1993). sAPPs have powerful neurotrophic and neuroprotective properties in vitro and may be involved in the containment of neuronal excitation and in the regulation of $\mathrm{Ca}^{2+}$-homeostasis (Mattson et al, 1993). Activation of a high conductance charybdotoxinsensitive $\mathrm{K}^{+}$-channel by sAPPs, leading to hyperpolarization of neurons and decrease of intracellular $\mathrm{Ca}^{2+}$-concentrations, has been proposed to be a major mechanism of SAPP effect on neuronal excitation (Furukawa et al, 1996).

In vitro, sAPPs can protect rat hippocampal cultures against the toxic effects of glutamate and hypoglycemia by a mechanism that may involve stabilization of the intraneuronal concentration of $\mathrm{Ca}^{2+}$ (Mattson et al, 1993). In vivo, moderate overexpression of sAPPs in transgenic mice confers resistance to acute and chronic forms of excitotoxicity, and has a synaptotrophic effect (Mucke et al, 1994, 1996). However, it is presently unclear whether sAPPs are also neuroprotective at physiological levels.

Physiological processing of $\beta$-APP is thought to occur predominantly by $\alpha$-secretase activity, resulting in peptide bond cleavage at position $16 / 17$ of $A \beta$ and secretion of the $\mathrm{N}$-terminal protein as SAPP and thereby precluding production of the pathogenic full-length $\mathrm{A} \beta$ (Sisodia et al, 1990). An alternative pathway probably includes internalization of $\beta$-APP and involves the endosomal/lysosomal pathway and $\beta$-secretase cleavage at the $N$-terminus of $A \beta$, resulting in the release of potentially amyloidogenic fragments containing $\mathrm{A} \beta$ sequences (Haass et al, 1992).

In Alzheimer's disease (AD), abnormal cleavage of $\beta$ APP by $\beta$-secretase activity is thought to result in enhanced levels and altered isoforms of $\mathrm{A} \beta$. One possible mechanism involves reduced amount and activity of protein kinase $\mathrm{C}$ (PKC) (Saitoh et al, 1991; Wang et al, 1994). Normally, activation of PKC can increase the rate of $\alpha$-secretase processing (Gillespie et al, 1992) and reduce the secretion of the amyloidogenic A $\beta$-peptide (Hung et al, 1993). In AD, the PKC defect may lead to the diversion of a greater proportion of $\beta$-APP towards $\mathrm{A} \beta$-forming pathways.

In addition, abnormal $\beta$-APP processing may also result in diminished levels of SAPPs. While $A \beta$-toxicity is thought to be the main pathogenetic principle underlying the neurodegeneration in AD, shortage of SAPPs has been proposed to contribute to the neurodegeneration by resulting in disturbed $\mathrm{Ca}^{2+}$ homeostasis and disinhibition of neuronal excitability (Furukawa et al, 1996). In 
congruence with this hypothesis, decreased levels of soluble amyloid beta-protein precursor have been found in cerebrospinal fluid of sporadic Alzheimer disease patients (Van Nostrand et al, 1992). Furthermore, decreased absolute and relative amounts of $\alpha$-secretasecleaved soluble amyloid beta-protein precursor were detected in cerebrospinal fluid of Alzheimer disease patients with the Swedish mutation APP $670 / 671$ (Lannfelt et al, 1995) and a PKC dependent deficiency in sAPP secretion was reported in fibroblasts from $A D$ patients (Bergamaschi et al, 1995).

Another conspicuous feature of $A D$ is the common occurrence of epileptic seizures and myoclonus. It is now recognized that $A D$ alone is an important risk factor for newonset epilepsy in older adults (Romanelli et al, 1990), with an incidence of seizures of up to ten times more than expected in a reference population (Hauser et al, 1986). Deficiency in SAPPs may contribute to the disinhibition of neuronal excitation underlying seizure generation by altering membrane potential and excitability (Furukawa et al, 1996).

To define the physiological properties of APP in vivo, we have taken advantage of mice with a targeted mutation in APP exon $2\left(\beta-\mathrm{APP}^{\Delta / \Delta}\right.$ mice). Due to missplicing and skipping of the targeted exon, these mice express no fulllength APP and low amounts of a modified form of APP $\left(\mathrm{APP}^{\Delta}\right.$ ) lacking amino acids 20-75 (Muller et al, 1994). Homozygous mutant mice are severely impaired in spatial learning and exploratory behavior, show reduced locomotor activity, reduced grip strength, retarded somatic growth and alterations in sensorimotor development (Muller et al, 1994). In addition, a high percentage of mutant mice on $129 S v(e v)$ genetic background show agenesis of the corpus callosum. However, no spontaneous neurodegeneration is apparent, no Alzheimer-type histopathological changes develop, and no spontaneous seizures are observed in $\beta$-APP ${ }^{\Delta / \Delta}$ mice.

To determine whether the lack of $\beta$-APP confers enhanced vulnerability to excitotoxicity, we challenged $\beta$ $\mathrm{APP}^{\Delta / \Delta}$ mice with injections of kainic acid (KA), and investigated the response of neuronal cultures of these mice to treatment with glutamate agonists. Kainic acid (KA) is a specific agonist of the kainate-subtype of glutamate receptors, which is expressed at high levels in the hippocampus (Lunn et al, 1996). Systemic administration of $\mathrm{KA}$ to rodents induces dose-dependent limbic and generalized seizures.

When mice with a deletion of the entire $\beta$-APP locus (APP ${ }^{\circ / o}$ mice) became available (Li et al, 1996), the seizure experiment was repeated to exclude a confounding effect of the mutant $\mathrm{APP}^{\Delta}$ in the previous experiments.

\section{Results}

\section{Seizure induction}

KA-induced behavioral alterations can be classified in three stages (Lothman et al, 1981): Stage 1 is defined as staring, stage 2 consists of automatisms and mild limbic convulsions. Stage 3 is characterized by severe limbic convulsions, including forelimb clonus and loss of righting, or by the occurrence of generalized tonic-clonic seizures and status epilepticus. By electroencephalography, stage 3 is characterized by bilateral cortical seizure activity. Barrel rotations are judged to be a particular severe form of motor seizures (Willcox et al, 1992), and can be induced by injections of KA or quinolinate into the striatum of rodents (Vescei and Beal, 1991), or by intraperitoneal administration of high doses of $\mathrm{KA}$. Visible seizures following intraperitoneal injection of KA in mice typically occur as forelimb clonus with sudden onset
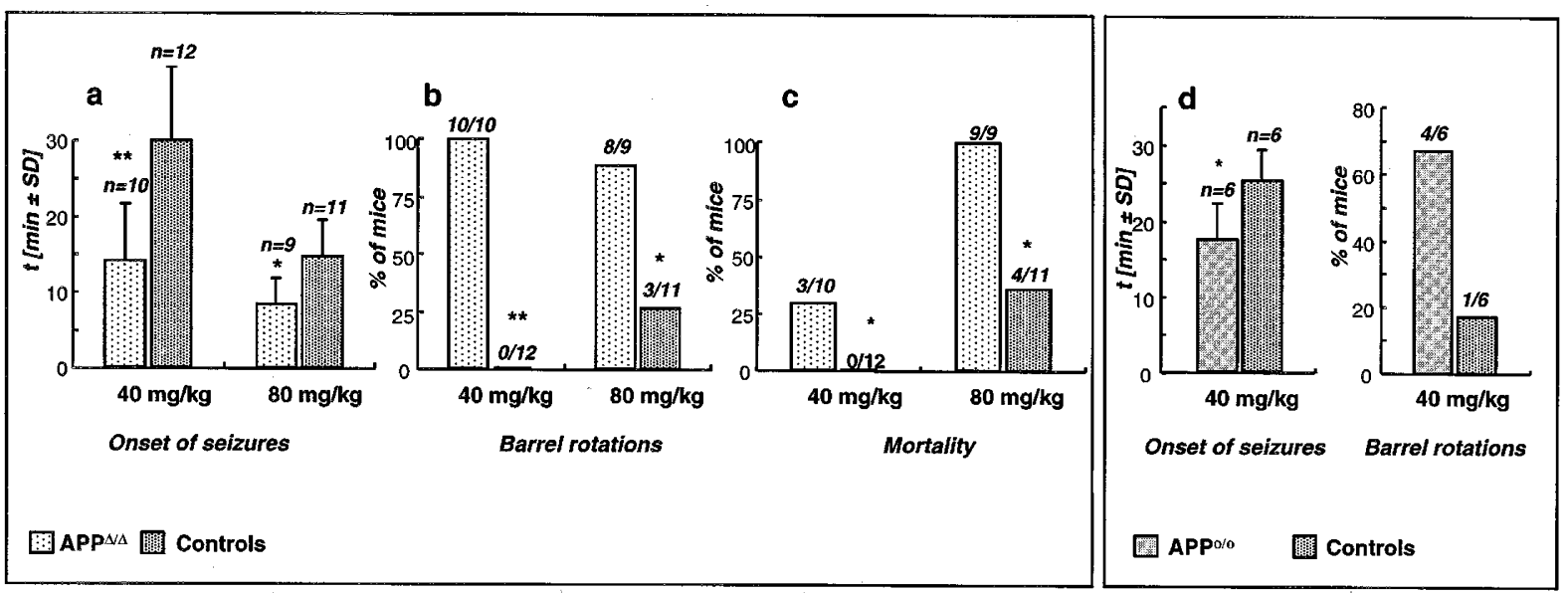

Figure 1 Response of $\beta$-APP ${ }^{\Delta / \Delta}$ mice and controls to i.p. injection of kainic acid. (a) Latency from injection of kainic acid to manifestation of seizures. At $40 \mathrm{mg} / \mathrm{kg}$ $\mathrm{KA}$, the mean time to the onset of seizures was $14.3 \mathrm{~min} v s 30.2 \mathrm{~min}$ in $\beta$-APP ${ }^{\Delta / \Delta}$ mice and controls, respectively $(P<0.001$, student's $t$-test). At $80 \mathrm{mg} / \mathrm{kg} \mathrm{KA}$, the mean time to the onset of seizures was $8.6 \mathrm{~min} v s 14.9 \mathrm{~min}(P=0.002$, student's $t$-test). (b) Occurrence of barrel rotations during seizures. At $40 \mathrm{mg} / \mathrm{kg} \mathrm{KA}$, all $\beta$ $\mathrm{APP}^{\Delta / \Delta}$ mice displayed barrel rotations, whereas none of the controls did $\left(P<0.001\right.$, chi-square test). At $80 \mathrm{mg} / \mathrm{kg} \mathrm{KA}, 8 / 9 \beta$-APP $\mathrm{K}^{\Delta / \Delta}$ mice and $3 / 11 \mathrm{controls}$ displayed barrel rotations $\left(P=0.006\right.$, chi-square test). (c) Mortality of seizures. At $40 \mathrm{mg} / \mathrm{kg} \mathrm{KA,} 3 / 10 \beta$-APP ${ }^{\Delta / \Delta}$ mice died, but none of the controls $(P=0.04$, chisquare test). At $80 \mathrm{mg} / \mathrm{kg} \mathrm{KA}$, all $\beta$-APP ${ }^{\Delta / \Delta}$ mice and $4 / 11$ controls died (P=0.003, chi-square test). Response of $\beta$-APP ${ }^{\circ / 0}$ mice and controls to i.p. injection of kainic acid. (d) At $40 \mathrm{mg} / \mathrm{kg} \mathrm{KA}$, the mean time to the onset of seizures was 17.4 min vs $25.2 \mathrm{~min}$ in $\beta$-APP ${ }^{\text {oo }}$ mice and controls, respectively ( $P=0.02$, student's $t$-test). $4 / 6$ $\beta$-APP ${ }^{\mathrm{o} / \mathrm{o}}$ mice displayed barrel rotations, whereas $1 / 6$ controls did ( $P=0.08$, chi-square test) 
after a prodromal phase characterized by nondiscriminative behavioral alterations. In this study, the time span from the injection of KA to the manifestation of overt motor seizures in the form of forelimb clonus, loss of righting, barrel rotations or generalized tonic-clonic seizures was defined as latency.

The latency from the time point of injection to the manifestation of epileptic seizures was significantly shortened in $\beta$-APP ${ }^{\Delta / \Delta}$ mice compared to wild-type controls (Figure 1a). The mean latency time at a dosage of $40 \mathrm{mg} /$ $\mathrm{kg} \mathrm{KA}$ was $14.3 \mathrm{~min}$ in $\beta$-APP ${ }^{\Delta / \Delta}$ mice versus $30.2 \mathrm{~min}$ in controls $(P<0.001)$, while at a dosage of $80 \mathrm{mg} / \mathrm{kg} \mathrm{KA}$ the latency was $8.6 \mathrm{~min}$ in $\beta-\mathrm{APP}^{\Delta / \Delta}$ mice versus $14.9 \mathrm{~min}$ in controls $(P=0.002)$.

Seizures were also more severe in $\beta$-APP ${ }^{\Delta / \Delta}$ mice (Figure 1b), with the appearance of barrel rotations in $100 \%$ of $\beta-\mathrm{APP}^{\Delta / \Delta}$ mice versus none of the controls at a dosage of $40 \mathrm{mg} / \mathrm{kg} \mathrm{KA}(P<0.001)$ and in $90 \%$ of $\beta$-APP ${ }^{\Delta / \Delta}$ mice vs $27 \%$ of controls at a dosage of $80 \mathrm{mg} / \mathrm{KA}$ $(P=0.006)$. In APP mutants, visible seizures often initiated directly with barrel rotations, without previous display of classical limbic seizures.

Acute mortality was also significantly enhanced in $\beta$ $\mathrm{APP}^{\Delta / \Delta}$ mice (Figure 1c). In the group receiving $40 \mathrm{mg} / \mathrm{kg}$ $\mathrm{KA}, 3 / 10$ mutants animals died in epileptic status in a rigid state (presumably due to ATP-depletion), compared to $0 / 12$ animals in the control group $(P=0.04)$. In the group receiving $80 \mathrm{mg} / \mathrm{kg} \mathrm{KA}, 9 / 9$ mutants died, compared to 4/ 11 animals in the control group $(P=0.003)$.

In the $\beta$-APP ${ }^{\circ / 0}$ mice homozygous for the deletion of the entire $\beta$-APP locus (Figure 1d), the mean latency time at a dosage of $40 \mathrm{mg} / \mathrm{kg} \mathrm{KA}$ was $17.4 \mathrm{~min}$ in $\beta$-APP ${ }^{\circ / \mathrm{o}}$ mice versus $25.2 \mathrm{~min}$ in controls $(P=0.02)$, with the appearance of barrel rotations in $4 / 6$ of $\beta$-APP $/ 0$ mice versus $1 / 6$ of the controls at a dosage of $40 \mathrm{mg} / \mathrm{kg} \mathrm{KA}(P=0.08)$. Therefore, $\beta$-APP ${ }^{\circ / 0}$ mice behaved similarly to $\beta$-APP ${ }^{\Delta / \Delta}$ mice with respect to KA hypersensitivity.

To determine whether callosal agenesis was responsible for the phenotype, we asked whether absence of the corpus callosum correlates with latency time and mortality for the groups of mutant animals and wild-type controls receiving $80 \mathrm{mg} / \mathrm{kg} \mathrm{KA}$ (Table 1). Agenesis of the corpus callosum was found in all $\beta-\operatorname{APP}^{\Delta / \Delta}$ mice $(n=9)$. However, in two groups of controls from independent experiments,

Table 1 No correlation of callosal agenesis and outcome of seizures

\begin{tabular}{|c|c|c|c|c|}
\hline Genotype & $\begin{array}{l}\text { Corpus } \\
\text { callosum }\end{array}$ & $n$ & $\begin{array}{l}\text { Latency to } \\
\text { seizure onset }\end{array}$ & Deaths (n) \\
\hline $\begin{array}{l}129 S v(e v) \\
129 S v(e v)\end{array}$ & $\begin{array}{l}\text { Agenesis } \\
\text { Normal }\end{array}$ & $\begin{array}{r}6 \\
15\end{array}$ & $\begin{array}{l}16.4 \pm 3.7 \\
13.5 \pm 5.8 \\
p(T)=0.2\end{array}$ & $p\left(\begin{array}{c}1 \\
8 \\
p\left(\chi^{2}\right)=0.125\end{array}\right.$ \\
\hline $\begin{array}{l}\text { 129Sv(ev) } \\
\beta-A P P^{\Delta / \Delta}\end{array}$ & $\begin{array}{l}\text { Agenesis } \\
\text { Agenesis }\end{array}$ & $\begin{array}{l}6 \\
9\end{array}$ & $\begin{array}{c}16.4 \pm 3.7 \\
8.6 \pm 3.2 \\
p(T)=0.005\end{array}$ & $p\left(\chi^{2}\right)^{\frac{1}{9}}=0.001$ \\
\hline
\end{tabular}

All animals were treated with $80 \mathrm{mg} / \mathrm{kg}$ kainic acid. Callosal agenesis is a frequent anomaly in 129 mice which are wild-type for the APP gene: however, neither latency of kainate-induced seizures nor mortality correlate significantly with callosal agenesis. Instead, both parameters correlate strongly with the $\beta$ $\mathrm{APP}^{\Delta / \Delta}$ genotype agenesis of the corpus callosum was found in $3 / 10$ and in 3/11 animals of $129 \mathrm{~Sv}(\mathrm{ev})$ genetic background.

Death occurred in a total of $8 / 15$ controls with normal corpus callosum and in 1/6 animals with agenesis ( $P=0.125$, chi-square-test). The mean latency time was $13.5 \mathrm{~min}$ in normal controls $v s 16.4 \mathrm{~min}$ in animals with callosal agenesis ( $P=0.2$, Student's $t$-test).

These data show no significant differences in the sensitivity to seizures and resulting mortality in 129Sv wild-type mice depending on the corpus callosum status, with a trend towards a less severe response to KA-induced seizures in mice with agenesis of the corpus callosum.

To exclude that the presence or absence of the corpus callosum was responsible for the differences of latency time and mortality observed between $\beta$-APP ${ }^{\Delta / \Delta}$ mice and controls, the subgroup of $129 \mathrm{~Sv}(\mathrm{ev})$ controls with callosal agenesis was compared to the group of $\beta-\mathrm{APP}^{\Delta / \Delta}$ mice (with callosal agenesis in all animals) at $80 \mathrm{mg} / \mathrm{kg} \mathrm{KA}$ (Table 1). Death occurred in $1 / 6$ controls with callosal agenesis and in 9/9 $\beta$ $\operatorname{APP}^{\Delta / \Delta}$ mice $(P=0.005$, chi-square-test). The mean latency time was $16.4 \mathrm{~min}$ in controls with callosal agenesis and 8.6 min in $\beta$-APP ${ }^{\Delta / \Delta}$ mice ( $P=0.001$, Student's $t$-test).

These data provide evidence for hypersensitivity to KAinduced seizures in $\beta$-APP ${ }^{\Delta / \Delta}$ mice independently from callosal agenesis.

\section{Induction of c-fos}

The temporo-spatial pattern of c-fos induction was investigated by in situ hybridization in order to obtain a measure of electrical activity and increased intracellular $\mathrm{Ca}^{2+}$-concentration following i.p. injection of KA. In the hippocampus, the pattern of $\mathrm{c}$-fos expression was largely similar in $\beta$-APP ${ }^{\Delta / \Delta}$ mice and controls. The expression pattern in the different sublayers had a characteristic dynamic development (Figure 2): 30 min after injection, expression was most pronounced in the dentate gyrus. At $60 \mathrm{~min}$, there was equally strong expression in the dentate gyrus and the CA1 layer, while at $120 \mathrm{~min}$, expression in the dentate gyrus had faded, and expression in the CA3 layer was becoming more prominent. Relative sparing of the CA2 sublayer was evident at all time points. Low levels of expression were observed in the hippocampus at very late time points ( $48 \mathrm{~h}$ and 7 days after injection) in single scattered cells in the CA1 and CA3 layers and in the dentate gyrus in both groups (not shown).

In contrast, in $\beta$-APP ${ }^{\Delta / \Delta}$ mice expression of $\mathrm{c}$-fos in the cortex and cingulate gyrus was enhanced compared to controls at all time points (Figure 2). This was true both for the absolute amount of staining and for the relative staining intensity in the cortex compared to the hippocampus.

In other areas with considerable basal or KA-induced expression of c-fos, such as amygdala and raphe nuclei, we found no recognizable differences in the amount of expression between groups. The expression in the hippocampus and cortex was generally bilateral and symmetric in both groups. Therefore, the phenotypic characteristic of enhanced susceptibility to seizures in $\beta$ $\mathrm{APP}^{\Delta / \Delta}$ mice is paralleled by elevated target gene transcription in the cortex and cingulate gyrus, but not in the hippocampus. 


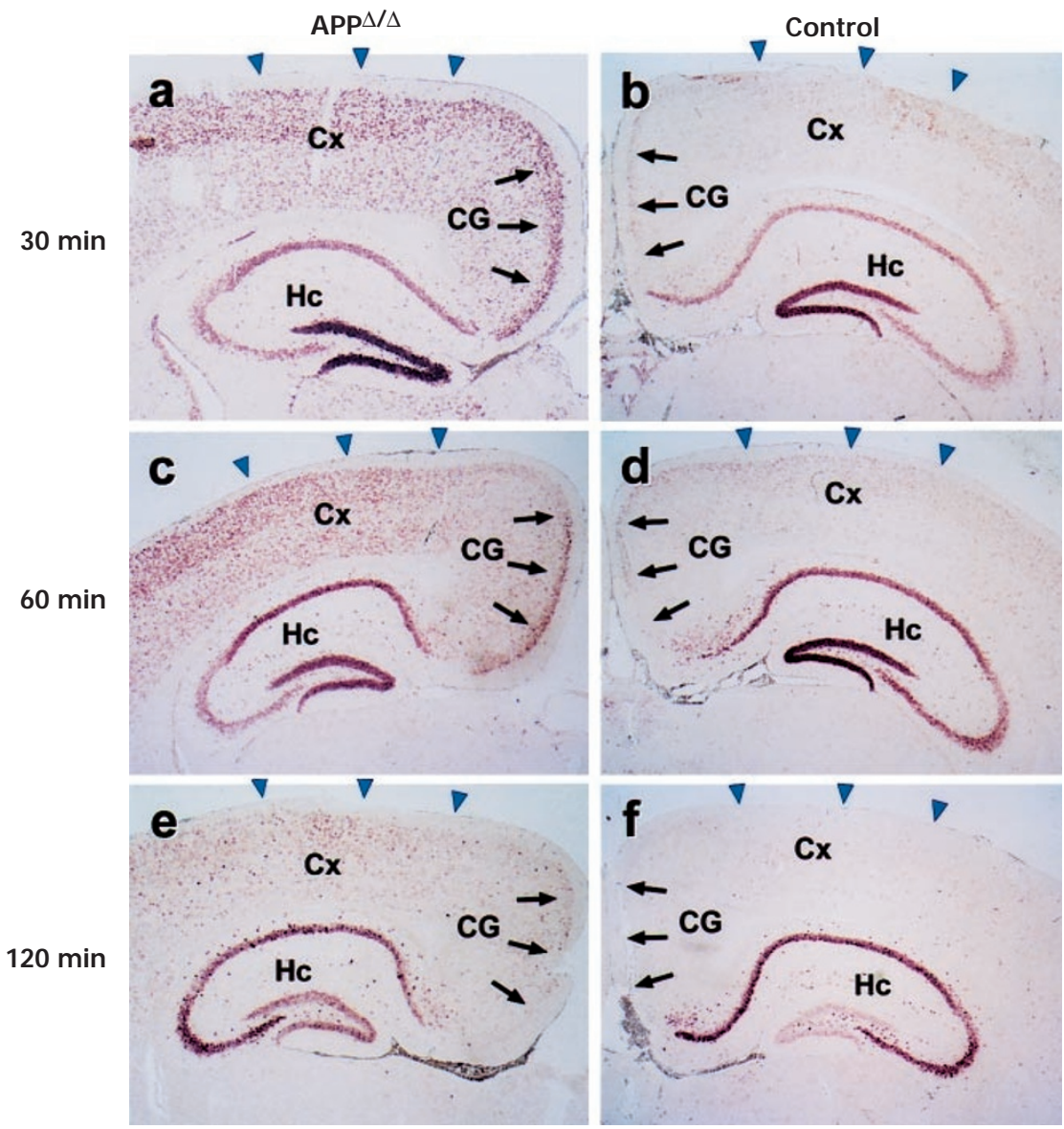

Figure 2 Temporo-spatial pattern of c-fos induction following i.p. injection of kainic acid. In-situ hybridization for c-fos: (a, b) 30 min after injection. (c, d) 60 min after injection. (e, f) 120 min after injection. In the hippocampus, the pattern of c-fos expression was largely similar in $\beta$-APP ${ }^{\Delta / \Delta}$ mice and controls. At 30 min expression was most pronounced in the dentate gyrus. At $60 \mathrm{~min}$, there was equally strong expression in the dentate gyrus and the CA 1 layer, while at 120 min expression in the dentate gyrus had faded, and expression in the CA3 layer was becoming more prominent. Note relative sparing of the CA2 sublayer. In contrast, in $\beta$-APP ${ }^{\Delta / \Delta}$ mice there was enhanced expression of $c$-fos in the cortex (arrowheads) and cingulate gyrus (arrows) compared to controls at all time points. CG, cingulate gyrus; $\mathrm{Cx}$, cortex; Hc, hippocampus

\section{Histopathologic changes}

Morphological damage to the hippocampus and cerebral cortex was assessed by histology and immunohistochemistry. Seven days after injection of $40 \mathrm{mg} / \mathrm{kg} \mathrm{KA}$, the most pronounced lesions were found in the CA3 sector of the hippocampus; in some animals also the CA1 sector was affected (2/7 $\beta$-APP ${ }^{\Delta / \Delta}$ and $5 / 12$ wild-type mice) (Figure 3a,b) as described previously (Schwob et al, 1980). In addition to neuronal loss, synaptodendritic damage was apparent in immunostains for synaptophysin and MAP-2, with visibly diminished neuropil density extending into the white matter of the hippocampus (Figure 3c,e). Analysis of surviving animals from both groups which had received $40 \mathrm{mg} / \mathrm{kg}$ kainic acid evidenced some variability in the morphological degree of tissue damage after 7 days. However, differences in the severity of lesions between the two groups were not larger than individual differences within each group.

The extent of TUNEL labeling in the hippocampal formation and in the cortex was also similar $48 \mathrm{~h}$ and 7 days after injections (Gillardon et al, 1995) (Figure 3g-k).

\section{Cytotoxicity in neuron cultures}

In order to test directly whether excitotoxicity due to glutamate receptor hyperstimulation was modified by $\beta$-APP deficiency, experiments were performed in primary neuronal cultures. Incubation of cerebellar granule cells (CGC) from wild-type or $\beta$-APP ${ }^{\Delta / \Delta}$ mice with different glutamate receptor agonists resulted in concentration-dependent, predominantly apoptotic cell death. The sensitivity of $\beta-\mathrm{APP}^{\Delta / \Delta}$ neurons was not significantly different from the one of wild-type neurons (Figure 4). Similar results were obtained when cultures of cortical neurons were exposed to glutamate $(10-1000 \mu \mathrm{M})$, kainic acid $(20-200 \mu \mathrm{M})$ or NMDA $(20-100 \mu \mathrm{M})$. Neither the time course nor the extent of toxicity were significantly different between wild-type or $\beta$-APP ${ }^{\Delta / \Delta}$ cultures after NMDA-exposure for 30 min only (Figure $5 a-d$ ) or glutamate exposure over the entire period of $24 \mathrm{~h}$ (Figure $5 \mathrm{e}$ ).

\section{Discussion}

We have observed that $\beta$-APP ${ }^{\Delta / \Delta}$ mice were more vulnerable 


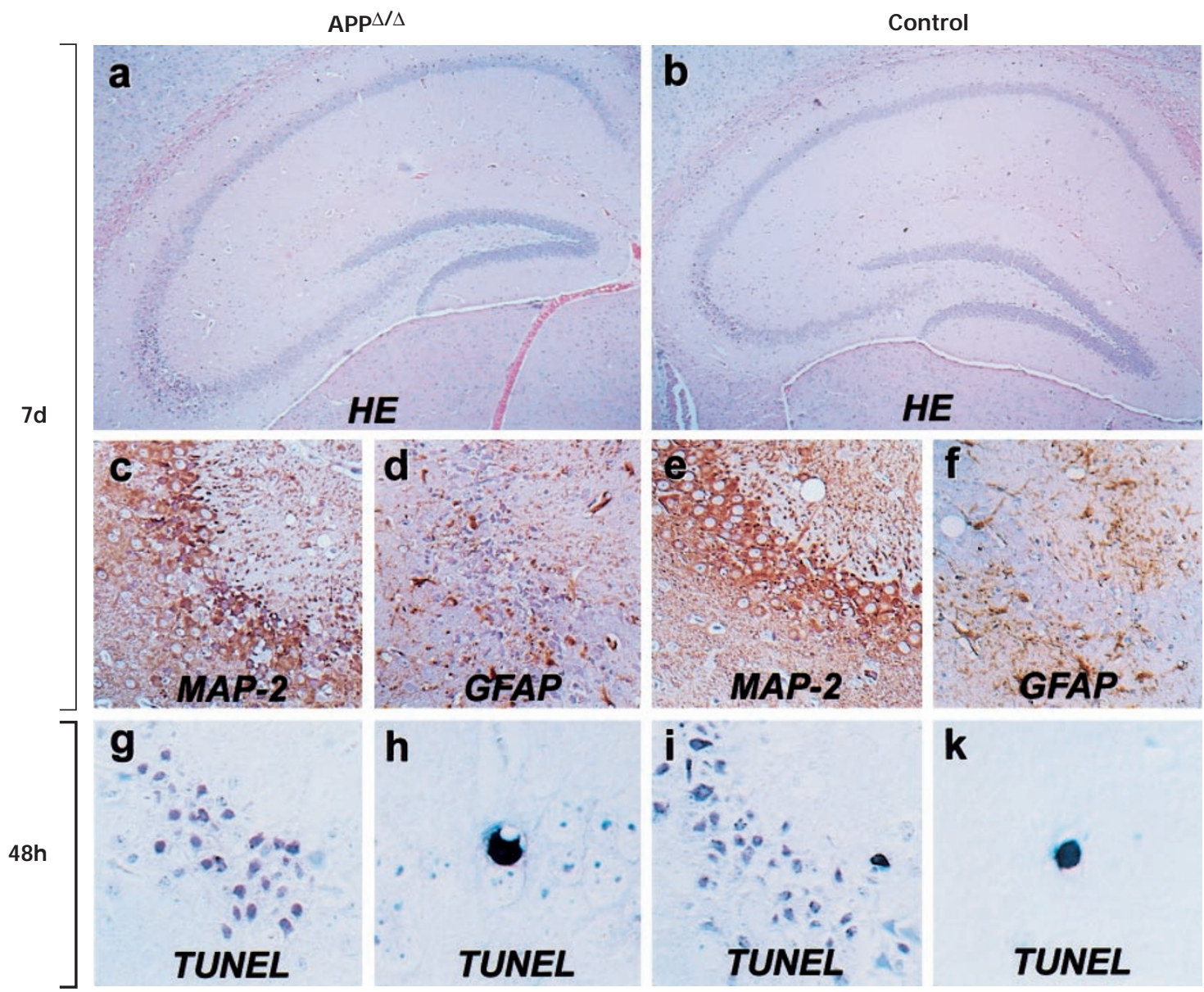

Figure 3 Tissue damage following i.p. injection of kainic acid. (a-f) Morphological changes after 7 days. (a, b) In both groups, nerve cell loss was most pronounced in the CA3 layer of the hippocampus, with diminished neuropil density in the adjacent white matter. HE staining. (c, e) Synaptodendritic damage is revealed by MAP-2 staining. (d, f) Reactive astrogliosis surrounding the pyramidal cell layer, GFAP staining. (g-k) Apoptosis after $48 \mathrm{~h}$. (g, i) In the CA3 layer, there were abundant pyknotic nuclei with evidence of DNA-fragmentation, TUNEL-staining. (h, $\mathbf{k})$ In addition, single apoptotic cells were found in the cortex, TUNEL-staining. No consistent differences in the amount and distribution of tissue damage and apoptosis were observed between groups

to kainic acid - induced epilepsy. Seizures started earlier, were more severe, and led to enhanced mortality compared to wild-type mice.

The visible manifestations of overt seizure activity were altered, with prominent appearance of barrel rotations, which are considered to be a more severe form of seizures than classical limbic seizures (Willcox et al, 1992). This is supported by the occurrence of barrel rotations also in some of the wild type controls at the high dosage of $80 \mathrm{mg} /$ $\mathrm{kg}$, but not at $40 \mathrm{mg} / \mathrm{kg}$ (Figure 1c). At very high dosages $(100 \mathrm{mg} / \mathrm{kg})$, barrel rotations were induced in most wildtype controls (data not shown). In addition, barrel rotations can be induced by direct stereotaxic injections of KA or quinolinate into the striatum of rodents (Vecsei and Beal, 1991). It is unclear, however, why in many $\beta-\mathrm{APP}^{\Delta / \Delta}$ mice visible seizures initiated directly with barrel rotations, without previous display of classical limbic seizures, such as forelimb clonus.

A high percentage of $\beta-\mathrm{APP}^{\Delta / \Delta}$ mice show agenesis of the corpus callosum (95\% on pure $129 \mathrm{~Sv}(\mathrm{ev})$ background), but this malformation is also observed at low frequency in the parental $129 \mathrm{~Sv}$ strain (approximately $15 \%$ of wild-type $129 \mathrm{~Sv}(\mathrm{ev})$ mice).

The corpus callosum is generally held to be a substrate for propagation, bilateralization and generalization of seizures, and section of the corpus callosum can be beneficial in most types of seizures (Spencer, 1988). However, in one study kainic acid induced seizures were aggravated by callosotomy in a rat model (Hirsch et al, 1992). This result was interpreted as evidence for an inhibitory influence of the non-epileptic hippocampus and neocortex on its contralateral homologue (Hirsch et al, 1992). In contrast, no data have been available on the effects of congenital agenesis of the corpus callosum towards the vulnerability to seizures. We have shown here, that $129 \mathrm{~Sv}(\mathrm{ev})$ wild-type mice with callosal agenesis are not more sensitive to KA-induced seizures (Table 1). There is even a trend towards a slight protection from the adverse effects of KA in the animals with callosal agenesis. In addition, the differences in latency time and mortality in the subgroup of controls with callosal agenesis compared to $\beta$ $\mathrm{APP}^{\Delta / \Delta}$ mice were undiminished and significant. Therefore, 


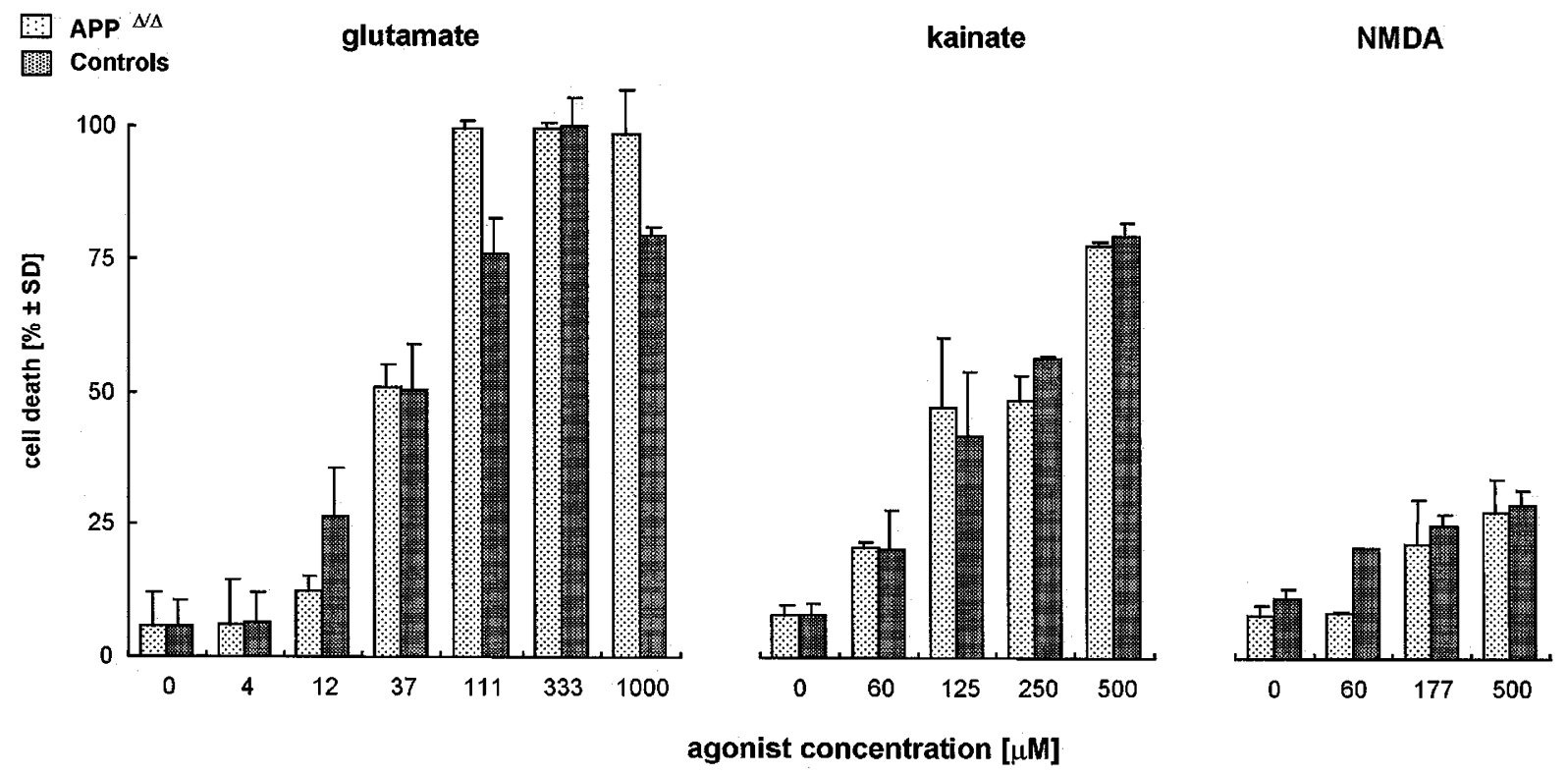

Figure 4 Glutamate receptor-mediated cytotoxicity in murine cerebellar granule cell cultures. CGC (8 DIV) from wild-type mice or $\beta$-APP ${ }^{\Delta / \Delta}$ mice were challenged in their original medium with the glutamate receptor agonists at the indicated concentrations. The percentage of cell death was quantitated $24 \mathrm{~h}$ later by counting of cells with condensed nuclei and broken plasma membrane. No significant differences in the susceptibility towards either glutamate agonist were found. Data are means \pm S.D. of three independent determinations

we can exclude the callosal agenesis as cause of the enhanced susceptibility to $\mathrm{KA}$-induced seizures in $\beta$-APP ${ }^{\Delta / \Delta}$ mice.

However, we could not formally exclude that the vulnerability to seizures is influenced by secretion of soluble $\mathrm{APP}^{\Delta}$ fragments with altered biological properties. Therefore, the seizure experiment was repeated with mice bearing a deletion of the entire $\beta$-APP locus (Li et al, 1996), to exclude a confounding effect of the mutant $\mathrm{APP}^{\Delta}$ in the previous experiments. Although only a small number of mice were available, which were more heterogeneous with regard to age and sex, and which were raised on a slightly different background $(129 \mathrm{~Sv}(\mathrm{ev}) \times 1290 \mathrm{Oa})$, the results confirmed enhanced vulnerability to seizures.

The bilateral and symmetric induction of c-fos in the cortex corresponds to the bilateral cortical seizure activity found during stage 3 seizures in electroencephalography (EEG) studies (Hirsch et al, 1992). The finding of enhanced induction of c-fos in the cortex and cingulate gyrus constitutes molecular evidence for augmented neuronal excitation in $\beta$-APP ${ }^{\Delta / \Delta}$ mice. Such enhanced excitability in the cortex may be the substrate of enhanced vulnerability to seizures and death. This may be a consequence of diminished neuronal inhibition due to loss of SAPP function, but an influence of corpus callosum agenesis on the induction of c-fos cannot be ruled out with certainty. The temporospatial expression pattern of c-fos in controls in this study was similar to that reported previously (Smeyne et al, 1992).

c-fos can act as a mediator of cell death and apoptosis in some systems (Hafezi et al, 1997), and the absence of enhanced structural damage to the hippocampus maps with the failure to detect enhanced induction of c-fos. In the cortex, there was elevated expression of $\mathrm{c}$-fos in $\beta$-APP ${ }^{\Delta / \Delta}$ mice, but the amount of apoptosis was generally low, with only some scattered TUNEL-positive cells detectable in both groups. Perhaps, cortical neurons from $\beta$-APP ${ }^{\Delta / \Delta}$ mice have a somewhat higher susceptibility to excitotoxic cell death, which does not become apparent under our experimental conditions. However, in vitro there were no differences in the vulnerability of $\beta$-APP ${ }^{\Delta / \Delta}$ and wild-type cortical neuronal cultures. Thus it is likely that $c$-fos expression merely provides a marker for KA induced target gene expression and does not mediate the induction of downstream processes of cell death.

There were no differences between $\beta-\mathrm{APP}^{\Delta / \Delta}$ mice and controls in the amount of morphological damage, synaptodendritic damage and extent of TUNEL labeling. Therefore, three independent lines of evidence support the conclusion that there is no enhanced tissue vulnerability to excitotoxic insult in $\beta$-APP ${ }^{\Delta / \Delta}$ mice.

A generally lower resistance to excitotoxic neuronal death was also not apparent in the in vitro studies. Both in cerebellar granule cell cultures and cortical cultures, the mode (i.e. apoptosis or necrosis) and amount of cell death following treatment with different glutamate receptor agonists was similar in both groups, and the thresholds of glutamate toxicity were the same. This appears to be in contrast with previous studies, which reported that SAPPs efficiently protect neurons against excitotoxicity in vitro (Mattson et al, 1993a,b). However, these pharmacological studies were performed in rats with exogenous SAPPs in addition to the endogenous SAPPs. The effects of loss of physiological amounts of SAPPs may be more subtle, and they can possibly be compensated by other factors, e.g. APP-like proteins (APLPS). 

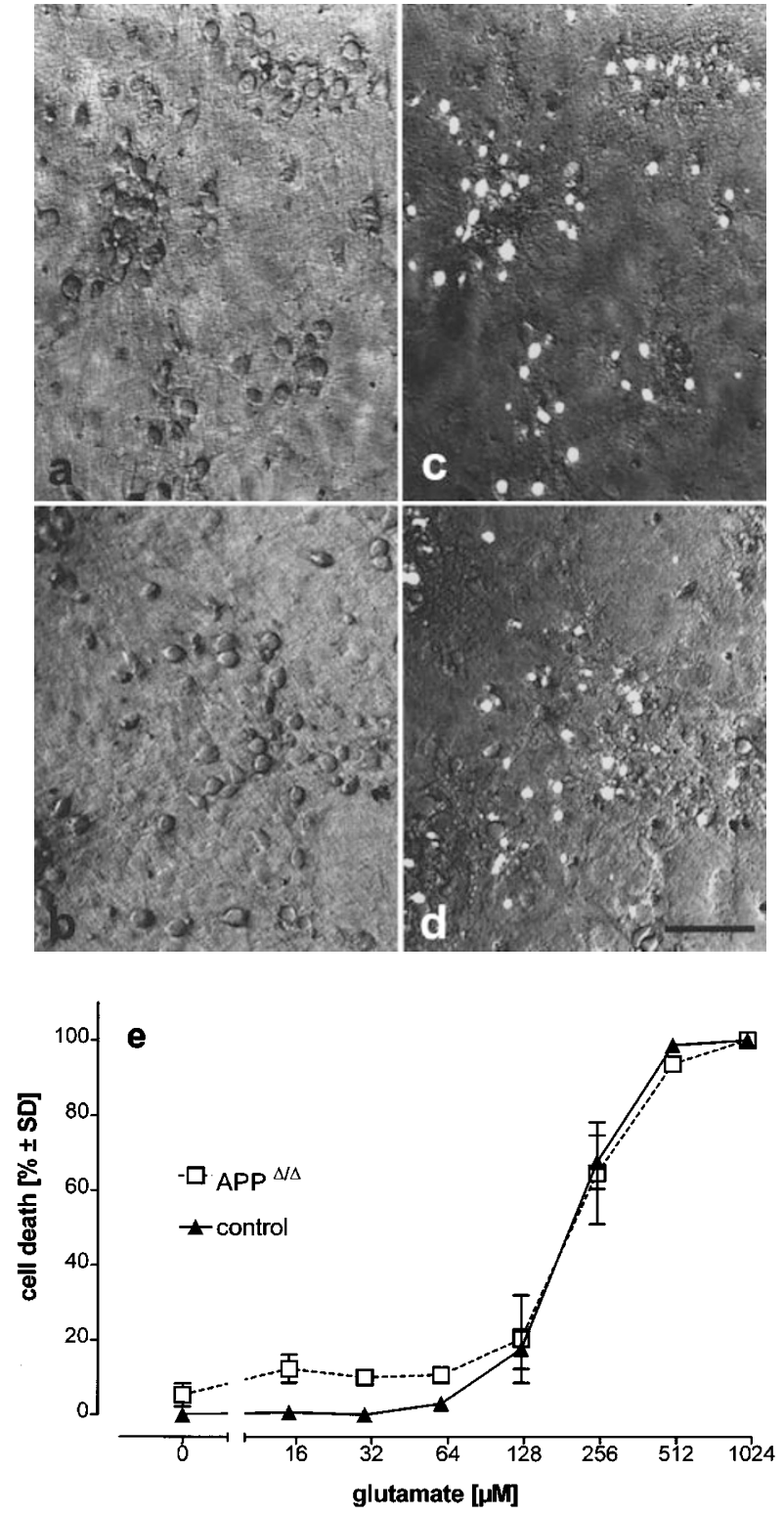

Figure 5 Glutamate receptor-mediated cytotoxicity in murine cortical neuron cultures. (a-d) Morphology of glutamate cytotoxicity on cortical neuron cultures. Cortical neuron cultures from wild-type mice $(\mathbf{a}, \mathbf{c})$ or $\beta-\mathrm{APP}^{\Delta / \Delta}$ mice (b, d) were imaged under phase contrast optics (a, b) and exposed to $50 \mu \mathrm{M}$ NMDA for $30 \mathrm{~min}$ in CSS-solution. After $24 \mathrm{~h}$ the membrane-impermeant DNAstaining dye SYTOX was added and the same fields were imaged by a combination of phase contrast and fluorescent microscopy (c, d). (e) Thresholds for glutamate toxicity. Cortical neurons (13 DIV) from wild-type mice or $\beta-\mathrm{APP}^{\Delta / \Delta}$ mice were challenged in their original medium with glutamate. The percentage of cell death was quantitated $24 \mathrm{~h}$ later by counting of remaining viable cells in the same fields. Data are means \pm S.D. of three independent determinations. Scale bar $=40 \mu \mathrm{m}$

During initial stages of sporadic AD, seizures are usually considered relatively infrequent, but tend to become more frequent toward the end of the clinical course (Hauser et al, 1986; Romanelli et al, 1990). However, in many kindreds affected by familial AD caused by $\beta$-APP or PS-1 mutations, seizures and myoclonic jerks are consistent early and prominent signs (Haltia et al, 1994), in some pedigrees affecting more than $80 \%$ of individuals (Lampe et al, 1994). This corresponds to pronounced misprocessing of $\beta$-APP with consequent reduction of $\alpha$-secretase cleared protective sAPPs (Lannfelt et al, 1995).

Our data support the hypothesis that SAPPs are involved in the containment of neuronal excitation in vivo, and that lack of sAPPs leads to diminished inhibition of the neuronal circuitry, and thereby lowers the threshold for seizure activity. Since $\mathrm{K}^{+}$channels are major determinants of membrane excitability (Tsaur et al, 1992), this is well compatible with in vitro data showing activation of a $\mathrm{K}^{+}$channel which modulates $\mathrm{Ca}^{2+}$ influx by SAPPs, thereby leading to hyperpolarization and suppression of action potentials (Furukawa et al, 1996).

Possibly, sAPPs serve to counteract the effect of $\mathrm{A} \beta$ itself, which can exert neurotoxic effects similar to glutamate in vitro. This is corroborated by data showing the efficiency of antiepileptic drugs against both glutamate and $\mathrm{A} \beta$-induced toxicity in rat hippocampal neurons (Mark et al, 1995).

On the other hand, the mechanism responsible for increased vulnerability to seizures did not result in enhanced susceptibility to cell death. It is possible that compensation by other factors such as APLPs may alleviate tissue damage. In addition, excitotoxic injury seems to depend mainly on $\mathrm{Ca}^{2+}$ influx via NMDA channels (Rothman and Olney, 1995). There is no evidence for a direct interaction of SAPPs with NMDA channels, and enhanced $\mathrm{Ca}^{2+}$ influx in $\beta$-APP ${ }^{\Delta / \Delta}$ mice may occur via pathways that are less detrimental. It has been demonstrated that $\mathrm{Ca}^{2+}$ entry into neurons through NMDAchannels causes substantially higher toxicity than similar elevations of cytosolic $\mathrm{Ca}^{2+}$ concentrations from other sources (Dugan et al, 1995; Tymianski et al, 1993).

While in $\beta$-APP ${ }^{\circ / 0}$ mice there is a complete absence of the $\beta$-APP gene, there may be also an additional loss of other relevant genes in the $200 \mathrm{~kb}$-spanning deletion. Conversely, there is a more subtle ablation of the $\beta$-APP gene in $\beta-\mathrm{APP}^{\Delta / \Delta}$ mice, but a small amount of a modified protein $\left(A P P^{\Delta}\right)$ is made. Since the results with both strains were congruent, we conclude that the lack of the $\beta$-APP gene is responsible for the observed hypersensitivity to KAinduced seizures rather than genetic artifacts of the recombination procedure or dominant effects of the mutant $\mathrm{APP}^{\Delta}$. In principle, the lack of the $\beta$-APP gene will result in lack of the membrane-spanning holo-APP, lack of SAPPs and lack of $A \beta$. Therefore, the observed phenotype may be due to the deficit of any of these three molecules. However, it appears most likely that the lack of SAPPs is responsible for the hypersensitivity to seizures, since $\mathrm{A} \beta$ is a strong neurotoxic agent itself, which facilitates excitotoxicity (Koh et al, 1990) and induces neuronal apoptosis (Loo et al, 1993), and holo-APP has not been shown to be neuroprotective. The concomitant lack of both $\mathrm{A} \beta$ and sAPPs may even mask the effects of the loss of the latter, since it has been hypothesized that SAPPs may protect against the toxic effects of $A \beta$ itself (Furukawa et al, 1996). In conclusion, our data suggest that reduced levels of sAPPs may contribute to the common occurrence of epileptic seizures in AD patients. 


\section{Materials and Methods}

\section{Animals}

$\beta$-APP ${ }^{\Delta / \Delta}$ mutants of pure $129 \mathrm{~Sv}(\mathrm{ev})$ background were bred and characterized as described previously (Muller et al, 1994). Agematched isogenic mice of $129 \mathrm{~Sv}(\mathrm{ev})$ substrain were used as controls. $\beta$-APP ${ }^{\circ / o}$ mice were bred on $129 \mathrm{~Sv}(\mathrm{ev}) \times 129$ Ola background. All procedures were in accordance with institutional guidelines and the federal laws for animal protection and European Community Council Directive 86/609/EEC.

\section{Seizure induction}

Groups of $9-12 \beta$-APP ${ }^{\Delta / \Delta}$ mice and controls aged 6 weeks to 3 months were injected intraperitoneally with kainic acid (Sigma) at concentrations of 40 and $80 \mathrm{mg} / \mathrm{kg}$. Groups of $6 \beta$-APP $/ \mathrm{o}$ mice and controls aged 4 weeks to 3 months were injected intraperitoneally with kainic acid (Sigma) at a concentration of $40 \mathrm{mg} / \mathrm{kg}$. Animals were placed in separate Plexiglas cages and monitored for onset of seizures.

\section{Histology}

Surviving animals were sacrificed 30,60 and $120 \mathrm{~min}, 48 \mathrm{~h}$ and 7 days following the injections of kainic acid. Brains were removed, fixed overnight in $4 \%$ (wt/vol) paraformaldehyde in PBS, and embedded in paraffin. Two $\mu \mathrm{m}$ coronal and sagittal sections were mounted on silanized slides and stained with hematoxylin and eosin (H\&E) and Luxol-Nissl. Immunohistochemistry was performed using polyclonal antibodies to glial fibrillary acidic protein (GFAP, DAKO, 1:300), synaptophysin (DAKO, 1:40) and microtubule associated protein-2 (MAP-2, Boehringer Mannheim, 1:1000). Biotinylated secondary antibodies (DAKO, 1:200), biotin/avidin-peroxidase (DAKO) and diaminobenzidine (Sigma) as chromogen were employed according to the instructions of the manufacturers.

\section{TUNEL}

In-situ nick end-labeling (TUNEL) was performed on sections of the hippocampus $48 \mathrm{~h}$ and 7 days after the injections, using the in-situ cell death detection kit II (Boehringer Mannheim). Slides were deparaffinized, and sections were digested with proteinase $\mathrm{K}(20 \mu \mathrm{g} / \mathrm{ml})$ for $15 \mathrm{~min}$ at $37^{\circ} \mathrm{C}$, followed by incubation with terminal transferase for $1 \mathrm{~h}$ at $37^{\circ} \mathrm{C}$ in the presence of fluorescein-labelled dUTP. An alkaline phosphatase coupled anti-fluorescein Fab fragment was used for detection, and 5-bromo-4-chloro-3-indolyl phosphate and 4-nitro blue tetrazolium (Boehringer Mannheim) were employed as chromogens.

\section{Cell cultures and cytotoxicity}

Cortical cultures of E15.5 embryos were prepared and cultured as described (Rose et al, 1993). Briefly, they were plated at a density of $3.2 \times 10^{5}$ /well in 24 well plates (Costar) with poly-L-lysine (PLL)coating or alternatively on a confluent monolayer of murine cortical glial cells. Medium was changed twice per week. Glial cell proliferation was arrested by addition of cytosine arabinoside $(10 \mu \mathrm{M})$ between day in vitro (DIV) $6-8$. At DIV11 cells were switched to serum-free medium and used for experiments at DIV13-17. Cerebellar granule cell cultures (CGC) were prepared from 8 day old newborn mice as described (Schousboe et al, 1989). Cells were seeded in 24 well plates coated with $50 \mu \mathrm{g} / \mathrm{ml} \mathrm{PLL}$ at a density of $0.75 \times 10^{6}$ cells $/ \mathrm{ml}$, treated with cytosine arabinoside after $48 \mathrm{~h}(10 \mu \mathrm{M})$ and used for experiments without medium change at DIV 7-10.
Apoptosis of CGC was quantitated as described in detail previously (Ankarcrona et al, 1995; Leist et al, 1997a). Cells were incubated briefly with a cell-permeant $(\mathrm{H}-33342)$ and a non-cell-permeant (ethidiumhomodimer-1) fluorescent chromatin stain. At early time points they showed a condensation of the chromatin and maintained the integrity of the plasma membranes. When cell death was quantitated after $24 \mathrm{~h}$, most nuclei of dead cells were condensed and the plasma membrane was broken. For viability assays in cortical neuron cultures, phase contrast/fluorescent images of defined fields (mask for $x$-y-coordinates) were recorded immediately prior to the start of the experiment and $24 \mathrm{~h}$ later. For visualization of broken plasma membranes, $0.5 \mu \mathrm{M}$ of the non-toxic, membrane impermeant chromatin stain SYTOX (Molecular Probes) was added to the culture medium (Leist et al, 1997b). The percentage of remaining viable neurons (morphological integrity and SYTOX-exclusion) was quantitated by counting of at least 300 cells. Incubations were performed either in culture medium for $24 \mathrm{~h}$ or in controlled salt solution ((CSS) in $\mathrm{mM}$ : $\mathrm{NaCl}, 116 ; \mathrm{KCl}, 5.4 ; 0.8 ; \mathrm{NaHCO}_{3}, 25$, glucose, 5.5, glycine, 0.1; HEPES, 12; $\mathrm{pH} 7.5$ ) for $30 \mathrm{~min}$ and post-incubation in medium for $24 \mathrm{~h}$. In control cultures the validity of the method was verified by comparison with results obtained in cultures that had been fixed and stained with antibodies against MAP-2.

\section{In situ hybridization}

Sense and antisense RNA probes were transcribed in vitro with $\mathrm{T} 3$ and T7 RNA polymerase from linearized plasmid pBFos (Hafezi et al, 1997 ) in the presence of digoxigenin-11-dUTP (Boehringer Mannheim, Germany). Fifty to $200 \mathrm{ng}$ of labeled transcripts were hybridized to paraformaldehyde fixed paraffin tissue sections at $65^{\circ} \mathrm{C}$ as described (Weissenberger et al, 1997). Digoxigenin was detected with alkaline phosphatase-labeled anti-digoxigenin Fab fragments and 4-nitro blue tetrazolium chloride/5-bromo-4-chloro-3-indolyl phosphate (Boehringer Mannheim, Germany).

\section{Acknowledgements}

We thank Marianne König, Heike Naumann, Chirine El-Ariss and Beatrice Pfister for technical assistance, and Norbert Wey for artwork. This work was supported by the Kanton of Zürich and by grants of the Swiss National Foundation and the Migros Foundation to AA.

\section{References}

Ankarcrona M, Dypbukt JM, Bonfoco E, Zhivotovsky B, Orrenius S, Lipton SA and Nicotera $P$ (1995) Glutamate-induced neuronal death: a succession of necrosis of apoptosis depending on mitochondrial function. Neuron 15: 961-973

Bergamaschi S, Binetti G, Govoni S, Wetsel WC, Battaini F, Trabucchi M, Bianchetti A and Racchi M (1995) Defective phorbol ester-stimulated secretion of betaamyloid precursor protein from Alzheimer's disease fibroblasts. Neurosci. Lett. 201:1-5

Dugan LL, Sensi SL, Canzoniero LM, Handran SD, Rothman SM, Lin TS, Goldberg MP and Choi DW (1995) Mitochondrial production of reactive oxygen species in cortical neurons following exposure to N-methyl-D-aspartate. J. Neurosci. 15: $6377-6388$

Furukawa K, Barger SW, Blalock EM and Mattson MP (1996) Activation of K+ channels and suppression of neuronal activity by secreted beta-amyloidprecursor protein. Nature 379: 74-78

Gillardon F, Wickert $\mathrm{H}$ and Zimmermann M (1995) Up-regulation of bax and downregulation of bcl-2 is associated with kainate-induced apoptosis in mouse brain. Neurosci Lett 192: 85-88

Gillespie SL, Golde TE and Younkin SG (1992) Secretory processing of the Alzheimer amyloid beta/A4 protein precursor is increased by protein phosphorylation. Biochem. Biophys. Res. Commun. 187: 1285-1290 
Haass C, Koo EH, Mellon A, Hung AY and Selkoe DJ (1992) Targeting of cell-surface beta-amyloid precursor protein to lysosomes: alternative processing into amyloid-bearing fragments. Nature 357: 500-503

Hafezi F, Steinbach JP, Marti A, Munz K, Wang ZQ, Wagner EF, Aguzzi A and Reme CE (1997) The absence of c-fos prevents light-induced apoptotic cell death of photoreceptors in retinal degeneration in vivo. Nat. Med. 3: 346-349

Haltia M, Viitanen M, Sulkava R, Ala Hurula V, Poyhonen M, Goldfarb L, Brown P, Levy E, Houlden H, Crook R et al (1994) Chromosome 14-encoded Alzheimer's disease: genetic and clinicopathological description. Ann. Neurol. 36: 362-367

Hauser WA, Morris ML, Heston LL and Anderson VE (1986) Seizures and myoclonus in patients with Alzheimer's disease. Neurology 36: 1226-1230

Hirsch E, Snead OC, Gomez I, Baram TZ and Vergnes M (1992) Section of the corpus callosum in kainic acid induced seizures in rats: behavioral, electroencephalographic and neuropathological study. Epilepsy Res. 11: 173-182

Hung AY, Haass C, Nitsch RM, Qiu WQ, Citron M, Wurtman RJ, Growdon JH and Selkoe DJ (1993) Activation of protein kinase C inhibits cellular production of the amyloid beta-protein. J. Biol. Chem. 268: 22959-22962

Koh J-Y, Yang LL and Cotman CW (1990) $\beta$-amyloid protein increases the vulnerability of cultured cortical neurons to excitotoxic damage. Brain Res. 533 : $315-320$

Lampe TH, Bird TD, Nochlin D, Nemens E, Risse SC, Sumi SM, Koerker R, Leaird B, Wier M and Raskind MA (1994) Phenotype of chromosome 14-linked familial Alzheimer's disease in a large kindred. Ann. Neurol. 36: 368-378

Lannfelt L, Basun H, Wahlund LO, Rowe BA and Wagner SL (1995) Decreased alphasecretase-cleaved amyloid precursor protein as a diagnostic marker for Alzheimer's disease. Nat. Med. 1: 829-832

Leist M, Fava E, Montecucco C and Nicotera P (1997a) Peroxynitrite and NO-donors induce neuronal apoptosis by eliciting autocrine excitotoxicity. Eur. J. Neurosci. 9: $101-111$

Leist M, Single B, Castoldi AF, Kühnle S and Nicotera P (1997b) Intracellular ATP concentration: a switch deciding between apoptosis and necrosis. J. Exp. Med. 185: $1481-1486$

Li ZW, Stark G, Gotz J, Rulicke T, Muller U and Weissmann C (1996) Generation of mice with a 200-kb amyloid precursor protein gene deletion by Cre recombinasemediated site-specific recombination in embryonic stem cells. Proc. Natl. Acad. Sci. USA 93: 6158-6162

Loo DT, Copani A, Pike CJ, Whittemore ER, Walencewicz AJ and Cotman CW (1993) Apoptosis is induced by beta-amyloid in cultured central nervous system neurons. Proc. Natl. Acad. Sci. USA 90: 7951-7955

Lothman EW, Collins RC and Ferrendelli JA (1981) Kainic acid-induced limbic seizures: electrophysiologic studies. Neurology 31: 806-812

Lunn ML, Ganakas AM, Mercer LD, Lawrence AJ and Beart PM (1996) Localisation and properties of AMPA-insensitive kainate sites: receptor autoradiography and gene expression in rat brain. Neurosci. Lett. 204: 121-124

MarkRJ, Ashford JW, Goodman Y and Mattson MP (1995) Anticonvulsants attenuate amyloid beta-peptide neurotoxicity, $\mathrm{Ca} 2+$ deregulation, and cytoskeletal pathology. Neurobiol. Aging 16: 187-188

Mattson MP, Barger SW, Cheng B, Lieberburg I, Smith Swintosky VL and Rydel RE (1993a) beta-Amyloid precursor protein metabolites and loss of neuronal Ca2+ homeostasis in alzheimer's disease. Trends Neurosci. 16: 409-414

Mattson MP, Barger SW, Cheng B, Lieberburg I, Smith Swintosky VL and Rydel RE (1993a) beta-Amyloid precursor protein metabolites and loss of neuronal Ca2+ homeostasis in alzheimer's disease. Trends Neurosci. 16: 409-414

Mattson MP, Cheng B, Culwell AR, Esch FS, Lieberburg I, Rydel RE. (1993b) Evidence for excitoprotective and intraneuronal calcium-regulating roles for secreted forms of the beta-amyloid precursor protein. Neuron 10: 243-254
Mucke L, Masliah E, Johnson WB, Ruppe MD, Alford M, Rockenstein EM, Forss Petter S, Pietropaolo M, Mallory M and Abraham CR (1994) Synaptotrophic effects of human amyloid beta protein precursors in the cortex of transgenic mice. Brain Res. 666: 151-167

Muller U, Cristina N, Li ZW, Wolfer DP, Lipp HP, Rulicke T, Brandner S, Aguzzi A and Weissmann C (1994) Behavioral and anatomical deficits in mice homozygous for a modified beta-amyloid precursor protein gene. Cell 79: 755-765

Nitsch RM, Farber SA, Growdon JH and Wurtman RJ (1993) Release of amyloid betaprotein precursor derivatives by electrical depolarization of rat hippocampal slices. Proc. Natl. Acad. Sci. USA 90: 5191-5193

Romanelli MF, Morris JC, Ashkin K and Coben LA (1990) Advanced Alzheimer's disease is a risk factor for late-onset seizures. Arch. Neurol. 47: 847-850

Rose K, Goldberg MP and Choi DW (1993) Cytotoxicity in murine neocortical cell culture. Meth. Toxicol. 1A: 46-60

Rothman SM and Olney JW (1995) Excitotoxicity and the NMDA receptor-still lethal after eight years. Trends Neurosci. 18: $57-58$

Saitoh T, Masliah E, Jin LW, Cole GM, Wieloch T and Shapiro IP (1991) Protein kinases and phosphorylation in neurologic disorders and cell death. Lab. Invest. 64: $596-616$

Schousboe A, Meier E, Drejer J and Hertz L (1989) Preparation of primary cultures of mouse (rat) cerebellar granule cells. In: A dissection and tissue culture manual of the nervous system, A Shahar, J de Vellis, A Vernadakis and B Haber, eds. (New York: Alan R. Liss), pp. 203-206

Schwob JE, Fuller T, Price JL and Olney JW (1980) Widespread patterns of neuronal damage following systemic or intracerebral injections of kainic acid: a histological study. Neuroscience 5: 991-1014

Selkoe DJ (1993) Physiological production of the beta-amyloid protein and the mechanism of Alzheimer's disease. Trends Neurosci. 16: 403-409

Sisodia SS, Koo EH, Beyreuther K, Unterbeck A and Price DL (1990) Evidence that beta-amyloid protein in Alzheimer's disease is not derived by normal processing. Science 248: $492-495$

Smeyne RJ, Schilling K, Robertson L, Luk D, Oberdick J, Curran T and Morgan J (1992) fos-lacZ transgenic mice: mapping sites of gene induction in the central nervous system. Neuron 8: 13-23

Spencer SS (1988) Corpus callosum section and other disconnection procedures for medically intractable epilepsy. Epilepsia 29 Suppl 2: S85-99

Tsaur ML, Sheng M, Lowenstein DH, Jan YN and Jan LY (1992) Differential expression of $\mathrm{K}+$ channel mRNAs in the rat brain and down-regulation in the hippocampus following seizures. Neuron 8: 1055-1067

Tymianski M, Charlton MP, Carlen PL and Tator CH (1993) Source specificity of early calcium neurotoxicity in cultured embryonic spinal neurons. J. Neurosci. 13: 2085-2104

Van Nostrand WE, Wagner SL, Shankle WR, Farrow JS, Dick M, Rozemuller JM, Kuiper MA, Wolters EC, Zimmerman J, Cotman CW. (1992) Decreased levels of soluble amyloid beta-protein precursor in cerebrospinal fluid of live Alzheimer disease patients. Proc. Natl. Acad. Sci. USA 89: 2551-2555

Vecsei $L$ and Beal MF (1991) Comparative behavioral and neurochemical studies with striatal kainic acid- or quinolinic acid-lesioned rats. Pharmacol. Biochem. Behav. 39: 473-478

Wang HY, Pisano MRand Friedman E (1994) Attenuated protein kinase C activity and translocation in Alzheimer's disease brain. Neurobiol. Aging 15: 293-298

Weissenberger J, Steinbach JP, Malin G, Spada S, Rülicke T and Aguzzi A (1997) Development and malignant progression of astrocytomas in GFAP-v-src transgenic mice. Oncogene 14: 2005-2013

Willcox BJ, Poulin P, Veale WL and Pittman QJ (1992) Vasopressin-induced motor effects: localization of a sensitive site in the amygdala. Brain Res. 596: 58-64 